\title{
ПРЕДМЕТНА ЮРИСДИКЦІЯ АДМІНІСТРАТИВНИХ СУДІВ: ШЛЯХ ЕВОЛЮЦІї ТА ОЦІНКА ПЕРСПЕКТИВ ІІЇ ЗВУЖЕННЯ У СВІТЛІ ЗАРУБІЖНОГО ДОСВІДУ
}

\author{
SUBJECT JURISDICTION OF ADMINISTRATIVE COURTS: \\ EVOLUTIONARY PATH AND ASSESSMENT OF THE PROSPECTS OF \\ ITS NARROWING IN LIGHT OF FOREIGN EXPERIENCE
}

\author{
Шевченко М. В. \\ доктор філософії в галузі права \\ ORCID: https://orcid.org/0000-0002-6708-016X
}

Mykhailo Shevchenko

Doctor of Philosophy in Law

\begin{abstract}
Досліджуються питання розвитку та перспектив перегляду меж юрисдикції адміністративних судів шляхом осмислення джерел потенціалу адміністративного судочинства та адміністративних судів щодо виконання поставлених перед ними завдань, механізмів та проявів еволюції практики адміністративного судочинства, а також вивчення зарубіжного досвіду організації судочинства у категоріях справ, які у юридичній спільноті пропонується вивести поза межі юрисдикції адміністративних судів. Визначено чинники, на яких грунтується потенціал адміністративної юстиції, з-поміж яких, зокрема, спеціалізація суддів та принципи адміністративного судочинства, які випливають з його природи та пристосовують загальний порядок здійснення правосуддя до особливостей адміністративного судочинства, пов'язаних із тим, що однією зі сторін завжди є суб'єкт владних повноважень, який має значно більш сприятливе становище для ведення справи, ніж його процесуальний опонент. Обгрунтовано, що у світлі зарубіжного досвіду виділення з юрисдикції вітчизняних адміністративних судів податкових спорів та передання їх до юрисдикції будь-яких інших судів не може мати жодного обгрунтування з точки зору найкращого захисту прав платників податків. Ключові слова: адміністративне судочинство, адміністративне судочинство у зарубіжних країнах, підвідомчість податкових спорів, предметна юрисдикція адміністративних судів, спір про право цивільне.
\end{abstract}

Исследуются вопросы развития и перспектив пересмотра границ юрисдикции административных судов путем осмысления источников потенциала административного судопроизводства и административных судов по выполнению поставленных перед ними задач, механизмов и проявлений эволюции практики административного судопроизводства, а также изучения зарубежного опыта организации судопроизводства в категориях дел, в юридическом сообществе предлагается вывести за пределы юрисдикции административных судов. Определены фракторы, на которых основывается потенциал административной юстиции, среди которых, в частности, специализация судей и принципы административного судопроизводства, вытекающих из его природы и приспосабливают общий порядок осуществления правосудия с особенностями административного судопроизводства, связанных с тем, что одной из сторон всегда есть субъект властных полномочий, имеет значительно более благоприятное положение для ведения дела, чем его процессуальный оппонент. Обосновано, что в свете зарубежного опыта выделения из юрисдикции отечественных административных судов налоговых споров и передачи их под юрисдикцию любых других судов не может иметь никакого обоснования с точки зрения наилучшей защиты прав налогоплательщиков. Ключевые слова: административное судопроизводство, административное судопроизводство в зарубежных странах, подведомственность налоговых споров, предметная юрисдикция административных судов, спор о праве гражданском.

The aspects of the development and prospects of revising the scope of jurisdiction of administrative courts are researched through understanding the sources of the potential of administrative court proceedings and administrative courts in fulfilling the tasks assigned to them, mechanisms and manifestations of the evolution of case-law of administrative courts, as well as through studying foreign experience in organizing legal proceedings in categories of cases proposed to be excluded from the scope of jurisdiction of administrative courts. The author determines the factors on which the potential of administrative justice is based, among which, in particular, the specialization of judges and the principles of administrative proceedings arising from its nature and designed to adapt the general court procedure to the peculiarities of administrative proceedings associated with the fact that one of the parties is always a public authority, having significantly more favorable position for making its case than his procedural opponent. It is substantiated that in the light of the foreign experience, separating tax disputes from the jurisdiction of administrative courts and transferring them to the jurisdiction of any other courts does not have any justification from the point of view of the best protection of the rights of taxpayers. Having carried out a comparative legal review of models for 
settlement of tax disputes, it is noted that a widespread legislative practice is to refer tax disputes to the jurisdiction of specialized tax courts (Germany and Canada - all tax disputes, Austria - disputes involving mostly national taxes and fees). In the United Kingdom, there are specialized tax chambers in general courts. Moreover, the author highlights that in the United Kingdom, procedural law provides for a special judicial review procedure designed to restore the rights of taxpayers violated by the improper use of discretion by regulators, which states that even in this common law country the classical principles of administrative justice are implemented. General and commercial courts have jurisdiction over only a small number of insignificant tax disputes in France alone, which clearly shows the incompatibility with the best world practice of the idea of referring tax disputes to the jurisdiction of commercial courts. Key words: administrative court proceedings, administrative court proceedings in foreign countries, civil law dispute, jurisdiction-relation of tax disputes, subject jurisdiction of administrative courts.

Постановка проблеми у загальному вигляді та її зв'язок із важливими науковими та практичними завданнями. Ухвалення у середині позаминулого десятиліття Кодексу адміністративного судочинства України (далі - КАС України) та розгортання мережі адміністративних судів створило міцний правовий та інституційний фундамент для того, щоб адміністративна юстиція якомога більшою мірою реалізувала її потенціал забезпечувати справедливе, неупереджене та своєчасне вирішення спорів між суб'єктами владних повноважень та фрізичними й юридичними особами, повне поновлення їх у правах, а також відповідальність суб'єктів владних повноважень за їх рішення, дії та бездіяльність.

Разом з тим, еволюційний шлях адміністративного судочинства нерідко супроводжується науковими та фаховими обговореннями питань звуження юрисдикції адміністративних судів через їх неефективність чи неспроможність виконувати поставлені перед ними завдання або з інших причин. Зокрема, у вітчизняній суддівській спільноті певного поширення та підтримки набула ідея про розвантаження касаційного адміністративного суду шляхом шляхом передання до предметної юрисдикції господарських судів всіх спорів, що виникають у сфері земельних відносин, а також податкових спорів, незалежно від суб'єктного складу учасників. У цьому контексті зауважується, що близько 30\% скарг, які знаходяться у Касаційному адміністративному суді, подані у справах, що виникають із податкових спорів. Передача їх на розгляд до Касаційного господарського суду пришвидшить їх вирішення та сприятиме подоланню проблеми із залишками справ [1].

Аналіз останніх досліджень і публікацій. Основоположне значення для належного наукового опрацювання питань еволюції та перспектив перегляду меж юрисдикції адміністративних судів мають фундаментальні наукові праці та міркування, зокрема, О. М. Пасенюка [2] та В. С. Стефанюка [3].

Виділення невирішених раніше частин загальної проблеми, котрим присвячується означена стаття. Значним внеском у подальше дослідження та науково обґрунтоване вирішення питань розвитку та перспектив перегляду меж юрисдикції адміністративних судів може бути докладне та ґрунтовне осмислення джерел потенціалу адміністративного судочинства та адміністративних судів щодо виконання поставлених перед ними завдань, механізмів та проявів еволюції практики адміністративного судочинства, а також вивчення зарубіжного досвіду організації судочинства у податкових справах у контексті обмірковування питання про виведення їх з меж юрисдикції адміністративних судів.

Виклад основного матеріалу дослідження. Насамперед, зауважимо, що потенціал адміністративної юстиції ґрунтується на декількох чинниках, одним з яких $є$ те, що розглядом та вирішенням адміністративних справ займаються судді з відповідною спеціалізацією, які діють у складі системи адміністративних судів, яка до того жє значною мірою самостійною та відокремленою. Як зазначив щодо цього один з батьків-засновників адміністративної юстиції В. С. Стефранюк, спеціалізована адміністративна юстиція забезпечує розгляд окремих категорій юридичних спорів найбільш компетентними фахівцями, що дозволяє дати їм адекватну правову оцінку і винести справедливе рішення. За словами класика адміністративного права, створення спеціалізованих адміністративних судів з розгляду спорів, що виникають між громадянами і публічним управлінням, відповідає ідеї про необхідність розширення правових гарантій особи як в адміністративно-юрисдикційному, так і в позитивному управлінському процесі. Необхідність надійного захисту прав, свобод і законних інтересів громадян вимагає формування якісно нового рівня правосуддя, яке могло б протидіяти зловживанням виконавчої влади, державними і самоврядними органами [3, с. 24].

Також, виконання адміністративним судочинством свого призначення гарантують його принципи, що випливають з його природи та покликані пристосувати загальний порядок здійснення правосуддя до виключних особливостей адміністративного судочинства, пов'язаних із тим, що однією зі сторін завжди є суб'єкт владних повноважень, який, як правило, має значно більш сприятливе становище для ведення справи, ніж його процесуальний опонент. Йдеться про те, що у спорах 3 приводу правомірності рішення, дії чи бездіяльності суб'єкта владних повноважень в судовому процесі позивачу протистоїть потужний адміні- 
стративний апарат із великим штатом фахівців, необмеженим доступом до інформації, яка має значення для ведення справи у адміністративному судочинстві, та іншими широкими організаційними та фінансовими можливостями.

Зважаючи на співвідношення процесуального становища суб'єктів владних повноважень та фрізичних й юридичних осіб, судова процедура вирішення публічно-правових спорів між ними ґрунтується, насамперед, на принципі офіційного з'ясування всіх обставин у справі, за яким адміністративний суд вживає визначені законом заходи, необхідні для з'ясування всіх обставин у справі, у тому числі щодо виявлення та витребування доказів з власної ініціативи (ч. 4 ст. 9 КАС України). Також, класична диспозитивність та змагальність сторін обмежується правилом про те, що суд може вийти за межі позовних вимог, якщо це необхідно для ефрективного захисту прав, свобод, інтересів людини і громадянина, інших суб'єктів у сфері публічно-правових відносин від порушень з боку суб'єктів владних повноважень. (ч. 2 ст. 9 КАС України). Більше того, діє презумпція протиправності рішень, дій чи бездіяльності суб'єкта владних повноважень із покладенням на нього обов'язку щодо доказування правомірності свого рішення, дії чи бездіяльності (ч. 2 ст. 77 КАС України) [4].

Однак, навіть мережі спеціалізованих адміністративних судів та найбільш досконалих правил адміністративного судового процесу недостатньо для того, щоб адміністративна юстиція забезпечувала ефективний захист від порушень 3 боку суб'єктів владних повноважень. Вирішальне значення також має юрисдикція адміністративних судів та охоплення нею усіх справ, які за їх юридичними властивостями мають розглядатись саме цими судами.

Еволюційний шлях вітчизняного адміністративного судочинства супроводжувався великими змінами поглядів суддів найвищих адміністративних судів на те, які справи підпадають під адміністративну юрисдикцію, а які мають залишатись поза нею. Загальні законодавчі критерії визначення цих справ завжди були такими, якими вони були у першій редакції КАС України (публічно-правовий спір, суб'єкт владних повноважень тощо), але бачення ознак цих критеріїв переглядалось у судовій практиці кардинально та революційно.

Одним з найбільш примітних підсумків років діяльності адміністративних судів $€$ величезна кількість виданих найвищими адміністративними судами правових позицій, у яких формувались та змінювались уявлення про критерії належності тих чи інших категорій правових спорів до публічно-правових з їх віднесенням до юрисдикції адміністративних судів. Як наслідок цих еволюційних процесів, насамперед, відбувалось та продовжує відбуватись уточнення ознак публічно-правового спору, який належить до юрисдикції адміністративних судів (публічно-владні управлінські функції тощо), та зі зміною розуміння цих ознак переглядається коло цих публічно-правових спорів із його розширенням та у відповідних випадках звуженням за рахунок відмежування від нього приватно-правових спорів (які мають розглядатись у загальних чи господарських судах).

Базовим положенням сучасного законодавства про адміністративне судочинство, що визначає юрисдикцію адміністративних судів є закріплене у п. 7 ч. 1 ст. 4 КАС України визначення суб'єкта владних повноважень як органу державної влади (у тому числі без статусу юридичної особи), органу місцевого самоврядування, їх посадової чи службової особи, іншого суб'єкта при здійсненні ними публічно-владних управлінських функцій на підставі законодавства, в тому числі на виконання делегованих повноважень, або наданні адміністративних послуг [4]. У цьому контексті привертає увагу те, що у первинній редакції КАС України викладалось майже таке само розуміння суб'єкта владних повноважень як органу державної влади, органу місцевого самоврядування, їхної посадової чи службової особи, іншого суб'єкта при здійсненні ними владних управлінських функцій на основі законодавства, в тому числі на виконання делегованих повноважень (п. 7 ч. 1 ст. 4 КАС України у редакції від 6 липня 2005 р.) [5].

Отже, за незмінності формулювань ключових ознак публічно-правового спору, підвідомчого адміністративним судам, їх юрисдикція зазнає масштабних та радикальних змін, під час яких судами встановлюється належність до приватно-правових тих спорів, які раніше традиційно вважались публічно-правовими, та навпаки. Також варто відзначити все ширше поширення юрисдикції адміністративних судів на спори, що пов'язані з виконанням делегованих повноважень, а також на деякі незвичайні категорії правових спорів.

Розпочинаючи докладний огляд цих тенденцій у практиці адміністративних судів, перш за все, слід висловити схвалення тією її частиною, яка підтверджує правильність розгляду за правилами адміністративного судочинства спорів, що пов'язані з виконанням делегованих повноважень суб'єктами, які не є органами державної влади чи місцевого самоврядування.

Наприклад, пам'ятною подією в історії розвитку вчення про адміністративну юрисдикцію $\epsilon$ її поширення на спори за участю організацій професійного самоврядування, що виконують у відповідних правовідносинах публічно-владні управлінські функції.

Так, у Постанові Верховного Суду України від 6 вересня 2016 р. у справі № 21-966а16 йдеться про те, що адвокатура як інституція та її діяльність в аспекті забезпечення реалізації конституційного 
права особи на правову допомогу набуває певних особливих властивостей суб'єкта публічних відносин. Ця властивість адвокатури увиразнюється (посилюється) метою її служіння суспільному інтересу шляхом надання своєчасної і належної правової допомоги у поєднанні з виконанням делегованих ӥй державою окремих владних повноважень. Отже, коли виникає спір із правовідносин, у яких адвокатура, як особлива фрормація реалізує надані їй правоможності в означеному сенсі, як-от у разі обмеження права особи на зайняття адвокатською діяльністю або прийняття рішення про зупинення або припинення права на заняття адвокатською діяльністю, оскарження рішення про накладення дисциплінарного стягнення, інші подібні за суттю і значенням дії, зокрема й щодо делегованих державною владних повноважень, то такий спір за наявності для цього підстав може підпадати під ознаки публічно-правового, на який поширюється юрисдикція адміністративних судів [6].

Так само, нещодавно у практиці Верховного Суду отримало підтвердження те, що адміністративними є справи за участю:

- Полтавської спеціалізованої школи-інтернату № 2 щодо нарахування та виплати одноразової грошової допомоги невиплати одноразової грошової допомоги випускнику з числа дітей, позбавлених батьківського піклування (Постанова Верховного Суду (Велика Палата) від 7 листопада 2018 р. у справі № 553/4650/14-а) [7]

- Комунального підприємства «Київблагоустрій» виконавчого органу Київської міської ради щодо виносення припису з вимогою про усунення порушень, невиконання якого $є$ підставою для демонтажу (Постанова Верховного Суду (Велика Палата) від 13 листопада 2018 р. у справі № 910/2145/18) [8];

- Українського центру оцінювання якості освіти, Державного підприємства «Інфоресурс» щодо зміни результатів зовнішнього незалежного оцінювання (Постанова Верховного Суду від 6 травня 2020 р. у справі № 761/9550/17) [9];

- Міжнародної благодійної організації «Екологія-Право-Людина» щодо заборону діяльності дельфрінарію «Оскар-Трускавець» ТОВ «Аквадельф» через порушення вимог екологічного законодавства - зверненням з таким позовом позивач фрактично замінює органи державної влади у питанні здійснення контролю за дотриманням природоохоронного законодавства (Постанова Верховного Суду (Велика Палата) від 11 грудня 2018 р. у справі № 910/8122/17) [10].

Таким чином, у практиці адміністративних судів активно розвивається теоретична основа для вирішення питання про те, чи здійснює той чи інший суб'єкт приватного права делеговані повноваження з виконанням владних публічних фрункцій. Суди досліджують сутність правовідносин та відповідних правових спорів, визначаючи, чи між суб'єктом делегованих владних повноважень і приватною особою складались відносини влади та підпорядкування, чи була діяльність суб'єкта делегованих владних повноважень спрямована на реалізацію публічного інтересу, чи містять його рішення ознаки веління, обов'язковості, ззовні виражаються у встановлених законом фрормах, а їх виконання забезпечується державним примусом. Більше того, адміністративна юрисдикція була поширена навіть на справи, у яких громадська організація діє не на підставі делегованих або будь-яких інших владних повноважень, але спрямовувалась на виконання владних управлінських фрункцій компетентного суб'єкта владних повноважень та реалізацію публічного інтересу, що розширює навіть класичні критерії вирізненння публічно-правових спорів відповідно до КАС України.

Поруч із цією тенденцією, все більш кристалізованими є критерії відмежування публічно-правових спорів, що належать до юрисдикції адміністративних судів, від приватно-правових спорів. Застосовуючи ці критерії, вдалось досягти великих перетворень у питаннях підвідомчості - зокрема, юрисдикційна належність деяких категорій правових змінилась повністю, інші вдалось, залежно від визначених обставин, поділити на публічно-правові та приватно-правові. Найбільш наочно це можна показати на прикладі спорів, що випливають з правовідносин, пов'язаних з державною реєстрацією, а також на прикладі земельних спорів.

Так, поглянувши на історію вирішення адміністративними судами питання про юрисдикцію справ про державну реєстрацію прав на нерухоме майно та їх обтяжень, помічаємо, що суди виходять, насамперед, з того, що якщо порушення своїх прав особа вбачає у наслідках, які спричинені рішенням, дією чи бездіяльністю суб'єкта владних повноважень, які вона вважає неправомірними, і ці наслідки призвели до виникнення, зміни чи припинення цивільних правовідносин, мають майновий характер або пов'язаний з реалізацією її майнових або особистих немайнових інтересів, то визнання незаконними (протиправними) таких рішень $є$ способом захисту цивільних прав та інтересів. Зважаючи на це, зараз усталеною $\epsilon$ правова позиція щодо того, що спір про визнання протиправними дій державного реєстратора щодо державної реєстрації права власності на нерухоме майно, скасування свідоцтва про право власності на нерухоме майно, скасування рішення про державну реєстрацію прав та їх обтяжень, внесення запису у Реєстр про скасування державної реєстрації права власності на нерухоме майно та внесення запису в Реєстр про державну реєстрацію права власності за іншою особою має розглядатися як спір, що пов'язаний з порушен- 
ням цивільних прав позивача на нерухоме майно іншою особою, за якою вже зареєстровано право власності на це майно. Більше того, цей спір є спором про цивільне право незалежно від того, здійснено державну реєстрацію прав на нерухоме майно з дотриманням державним реєстратором вимог законодавства чи ні (Постанова Верховного Суду (Велика Палата) від 21 листопада 2018 р. у справі № 804/8507/15) [11].

Отже, якщо рішення або дії суб'єкта владних повноважень на виконання владних управлінських функцій призводять до виникнення, зміни або припинення цивільних прав, а їх оскарження є способом поновлення порушених, невизнаних або оспорюваних цивільних справ, то має місце спір про право цивільне, а не публічно-правовий спір.

Цей само критерій є застосовним за відповідних обставин, наприклад, до спорів з приводу державної реєстрації юридичних осіб та фрізичних осіб - підприємців, змін до установчих документів юридичних осіб. Так, у справі № 815/3490/16 Верховий Суд, встановивши, що з висловлених позивачем у ході розгляду справи мотивів звернення до суду вбачається, що незаконність, на думку позивача, дій державного реєстратора при здійсненні ним реєстраційних дій є наслідком незаконного призначення на посаду директора підприємства, якого не обирали на загальних зборах товариства, визначив, що спірні правовідносини виникли між учасниками підприємства щодо їх повноважень в управлінні цією юридичною особою, а саме, призначенні виконавчого органу цього товариства - директора, а тому дії державного реєстратора вчинення запису про особу як директора підприємства у цих відносинах є похідними. Інакше кажучи, оскаржуються реєстраційні дії, яким передує невирішений корпоративний спір, у межах якого можуть бути розв'язані й питання, пов'язані з реєстрацією змін керівника юридичної особи та зміни складу або інформації про засновників, а тому цей спір не пов'язаний із захистом прав, свобод чи інтересів позивача та третіх осіб у сфері публічно-правових відносин від порушень з боку органів державної влади, що виключає його розгляд у порядку адміністративного судочинства [12].

Таким чином, навіть за умови, що у спірних правовідносинах суб'єкт владних повноважень виконує владні управлінські фрункції, якщо протиправність відповідних рішень чи дій суб'єкта владних повноважень обгрунтовується, передусім, порушенням цивільних прав та інтересів, то оцінка рішенням чи діям суб'єкта владних повноважень має даватись під час вирішення приватно-правових спорів у загальних або господарських судах, вирішення яких у адміністративних судах $є$ неможливим через те, що у них немає цілей (відповідно до завдання адміністративного судочинства) та повноважень перевіряти правомірність правочинів чи інших підстав виникнення цивільних прав та обов'язків, що $є$ неминучим для належного вирішення справи.

Отже, адміністративна юстиція упродовж історії іï існування пріоритезує ефективний захист прав від порушень з боку суб'єктів владних повноважень, послідовно та переконливо обгрунтовуючи належність до юрисдикції адміністративних судів тих справ, у яких суб'єкт владних повноважень виконував владні управлінські функції, з чого виник спір, який за природою є публічно-правовим. 3 іншого боку, вітчизняна судова система дійшла згоди про невтручання адміністративних судів у вирішення спорів, у яких домінуючою є приватно-правова складова та первинним питанням $€$ захист цивільних прав.

Водночас, вкрай важливим є утвердження думки про поширення положень законодавства про адміністративне судочинство та юрисдикції адміністративних судів на справи, що характеризуються усіма ознаками справ адміністративної юрисдикції.

Податкові спори є чи не найбільш очевидним прикладом публічно-правових спорів, що мають вирішуватись у адміністративних судах, оскільки у податкових правовідносинах, які є цілком публічно-прваовими, контролюючий орган є суб'єктом владних повноважень, який здійснює у цих правовідносинах владні управлінські функції.

Податкові спори за споконвічною судовою практикою вітчизняних адміністративних судів вважаються такими, що охоплюються юрисдикцією адміністративних судів. Так, наприклад, у справі № 805/1983/17а Велика Палата Верховного Суду вказала на те, що правовідносини, які виникають під час виконання державною фріскальною службою та її територіальними органами покладених на них завдань, є публічно-правовими, а справи зі спорів з суб'єктами цих відносин є адміністративними [13].

Все ж, за міркуваннями О. М. Пасенюка відсутня правова стабільність у питанні про юрисдикційну належність спорів: щодо оскарження рішень, дій чи бездіяльності податкових органів у сфері адміністрування податків. Звертається увага на те, що господарський процесуальний кодекс фактично будь-який спір за участю суб'єкта господарювання відносить до господарської юрисдикції та немає гарантій, що в майбутньому ці суди на основі довільного тлумачення словосполучення «та з інших підстав» не змінять свою позицію [2]. Також у цьому зв'язку прийнято зазначати, що рішення контролюючих органів впливають на господарську діяльність й на майнові права та інтереси платника податків. Однак, зважаючи на вищенаведені аргументи на користь належності податкових спорів до юрисдикції адміністративних судів, а також на те, якою є юрисдикційна належність податкових спорів та процесуальні правила 
їх вирішення, будь-яких подібних деструктивних та безпідставних сумнівів бути не може. Між контролюючим органом і приватною особою складаються відносини влади та підпорядкування, діяльність контролюючого органу спрямована на реалізацію виключно публічного інтересу (жодних цивільних прав ні в кого не виникає), рішення контролюючого органу містять ознаки веління, обов'язковості, ззовні виражаються у встановлених законом фрормах, а їх виконання забезпечується державним примусом.

Взагалі, світова практика організації вирішення податкових спорів у судах показує велике різноманіття рішень щодо того, якими мають бути юрисдикційна належність та судова процедура вирішення податкових спорів.

Наприклад, процесуальне законодавство Нiмеччини відносить податкові спори до юрисдикції фіскальних судів, які під час їх розгляду та вирішення керуються кодексом судових процедур для фріскальних судів [14].

Правила доказування є звичайними: як правило, податковий орган має довести факти, що вказують на обгрунтованість податкових донарахувань та/або штрафів, тоді як платник податків має спростувати ці факти. Будь-які обставини справи вважаються встановленими, якщо немає щодо них розуміного сумніву [15].

За законодавством Австрії судове оскарження рішень контролюючих органів відбувається шляхом звернення до фредерального податкового суду або адміністративного суду відповідного федерального штату. Федеральний податковий суд має повноваження вирішувати податкові спори, що стосуються визначених податковими органами зобов'язань щодо сплати федеральних податків, 3-поміж яких податок на доходи фізичних осіб, податок на прибуток підприємств, податок на додану вартість, податок на відчуження нерухомого майна, податок на споживання та гербовий збір. Спори, що пов'язані з адмініструванням та відповідальністю за сплату провінційних та муніципальних податків та зборів (туристичний збір тощо), належать до юрисдикції адміністративних судів штатів. При цьому, під час розгляду податкових справ усі австрійські суди керуються принципом офріційного з'ясування обставин у справі та очікують від контролюючих органів належного обгрунтування податкових донарахувань та штрафів [16].

Подібний юрисдикційний розподіл податкових справ передбачений законодавством Франції, у якій адміністративним судам підвідомчі спори щодо основних податків (податок на доходи фізичних осіб, податок на прибуток підприємств, податок на додану вартість, деякі місцеві податки), тоді як у загальних судах розглядаються справи про оскарження рішень контролюючих органів щодо податку на майно (у зв'язку з успадкуванням або даруванням, податок на богатство) та деяких інших місцевих податків невеликого значення. Також, так само, як й у Австрії, на французькі податкові органи покладається обов'язок доказування правомірності їх рішень, крім особливих випадків, коли платник податків скористався правом на адміністративне оскарження рішень податкових органів до комітету з податкових зловживань і цей комітет постановить, що мало місце податкове шахрайство [17].

Звернувшись до досвіду найбільш розвинених країн загального права, дізнаємось, що у Сполученому Королівстві більша частина вимог, що випливають з податкових спорів, розглядається податковими палатами звичайних судів: трибуналу першої ланки (перша інстація) та вищого трибуналу (друга інстанція). Однак, у особливих випадках платник податків може скористатись спеціальною процедурою судового контролю (judicial review) зі спрямуванням справи до Адміністративного суду Високого суду Сполученого Королівства. Це $€$ можливим, якщо:

- окаржуються дискреційні рішення, дії чи бездіяльність контролюючого органу, серед яких, поновлення пропущеного строку, застосування приписів податкового законодавства за виключних обставин;

- законодавством не встановлено право на оскарження рішення, дії чи бездіяльності контролюючого органу;

- посадова особа контролюючого органу допускає бездіяльність, діяє з невиправданою затримкою або з перевищенням повноважень тощо [18].

При цьому, за процесуальними правилами, що стосуються як звичайного порядку розгляду справи, так й процедури судового контролю, суди наділяються широкими повноваженнями щодо управління судовим процесом, зокрема, за власною ініціативою зобов'язувати сторін у справі давати пояснення або подавати докази [19]. Також, примітним $є$ те, що тягар доказування покладається на контролюючі органи, які мають показати на основі балансу вірогідностей, що платник податків допустив податкове правопорушення, на яке контролюючий орган відреагував справедливо та розумно [20].

Для порівняння, у Канаді виключна компетенція щодо судового розгляду публічно-правових спорів за участю податкових органів закріплюється за спеціалізованими податковими судами [21, с. 74].

При цьому, стандарти доказування у цих спеціалізованих подактових судах значно відрізняються від тих, які властиві класичному адміністративному судочинству. Так, на канадській подтковій службі лежить тягар доказування законності та обгрунтованості податкових фінансових санкцій. Разом 3 тим, податковий орган має перевагу покладатись 
на фрактичні припущення, викладені у матеріалах податкових перевірок. Платник податків, який з ними не погоджується, має спростувати ці фракти (адже він у рамках системи самодекларування має усю інформацію про свою фрінансово-господарську діяльність), а суд ухвалюватиме рішення на основі балансу вірогідностей [21, с. 75-77].

Висновки з цього дослідження. Підбиваючи підсумки порівняльно-правового огляду моделей організації судового вирішення податкових спорів, слід зазначити, що широко поширеною законодачою практикою $є$ віднесення податкових спорів до компетенції спеціалізованих податкових судів (Німеччина та Канада - усі податкові спори, Австрія - спори, що стосуються переважно загальнодержавних податків та зборів). У Сполученому Королівстві при загальних судах діють спеціалізовані податкові палати.

Юридсикція адміністративних судів охоплює справи про адміністрування та відповідальність платників податків за сплату найбільш значущих податків у Франції та місцевих податків у Австрії. У Сполученому Королівстві процесуальним законодавством передбачається особлива процедура судового контролю, призначена для відновлення прав платників податків, порушених неналежним використанням контролюючими органами їх дискреційних повноважень, що дозволяє констатувати, що навіть у цій країні впроваджуються класичні засади адміністративного судочинства.
Загальним та господарським судам підвідомчими є лише частина малозначних податкових спорів тільки у Франції, що однозначно показує несумісність із найкращою світовою практикою ідей про віднесення податкових спорів до юрисдикції цих судів.

Разом з тим, загальною тенденцією, яка простежується в усіх країнах $€$ те, що компетентний суд під час розгляду та вирішення податкових справ дотримується тих самих основних засад адміністративного судочинства, як вони відображені у КАС України, керуються принципом офційного з'ясування обставин у справі, а тягар доказування правомірності рішень, дій та бездіяльності податкових органів покладається на них самих.

Таким чином, процесуальна модель вирішення податкових спорів, яка діє в Україні, цілком узгоджується із найкращою світовою практикою у питаннях забезпечення захисту прав платників податків від порушень з боку контролюючих органів. Зважаючи на це, виділення з юрисдикції вітчизняних адміністративних судів податкових спорів та передання їх до юрисдикції будь-яких інших судів не може мати жодного обгрунтування з точки зору найкращого захисту прав платників податків. Адміністративні суди та правила адміністративного судочинства $€$ оптимальними механізмами у цій справі, а їх еволюція, як й попередні роки адміністративної юстиції має відбуватись поступово, без радикальних змін цієї моделі.

\section{БІБЛІОГРАФІЧНИЙ СПИСОК:}

1. Запропоновані законопроектом № 2314 фрільтри сприятимуть забезпеченню єдності судової практики, - член Комісії з питань правової реформи Роман Бойко. Судово-юридична газета. 2019. URL: https://ki.arbitr. gov.ua/sud5011/pres-centr/interview/855463/.

2. Пасенюк О. М. Колізії між адміністративною та господарською юрисдикцією: шляхи їх подолання. Юрінком Iнmep. 2018. URL: https://yurincom.com/legal_practice/analitychna_yurysprudentsiia/kolizii-mizh-administratyvnoiuta-hospodarskoiu-iurysdyktsiieiu-shliakhy-ikh-podolannia/.

3. Стефранюк В.С. Судовий адміністративний процес: монографрія. Харків: Фірма «Консум», 2003. 464 с.

4. Кодекс адміністративного судочинства України : Закон України від 6 липня 2005 року № 2747-IV. Дата оновлення: 5 серпня 2021 року. URL: https://zakon.rada.gov.ua/laws/show/2747-15\#n9495.

5. Кодекс адміністративного судочинства України : Закон України від 6 липня 2005 року № 2747-IV. URL: https://zakon.rada.gov.ua/laws/show/2747-15/ed20050706/conv\#Text.

6. Постанова Верховного Суду України від 6 вересня 2016 р. у справі № 21-966a16. URL: https://protocol.ua/ua/ vcu_pidtverdiv_viklyuchne_pravo_advokativ_samostiyno_virishuvati_spirni_pitannya_shchodo_samovryadnosti/.

7. Постанова Верховного Суду (Велика Палата) від 7 листопада 2018 року у справі № 553/4650/14-а (K/9901/1396/18). URL: http://reyestr.court.gov.ua/Review/77801686.

8. Постанова Верховного Суду (Велика Палата) від 13 листопада 2018 року у справі № 910/2145/18. URL: http://reyestr.court.gov.ua/Review/78044739.

9. Постанова Верховного Суду від 6 травня 2020 року у справі № 761/9550/17. URL: http://reyestr.court.gov. ua/Review/89621251.

10. Постанова Верховного Суду (Велика Палата) від 11 грудня 2018 року у справі № 910/8122/17. URL: http://reyestr.court.gov.ua/Review/78977479.

11. Постанова Верховного Суду (Велика Палата) від 21 листопада 2018 року у справі № 804/8507/15. URL: http://reyestr.court.gov.ua/Review/78129846.

12. Постанова Верховного Суду (Велика Палата) від 28 листопада 2018 року у справі № 815/3490/16. URL: http://reyestr.court.gov.ua/Review/78299081.

13. Постанова Верховного Суду (Велика Палата) від 21 листопада 2018 року у справі № № 805/1983/17а. URL: https://protocol.ua/ru/postanova_vp_vs_vid_21_11_2018_roku_u_spravi_805_1983_17_a/.

14. Federal Administrative Court of the Federal Republic of Germany. Administrative Jurisdiction. URL: https:// 
www.bverwg.de/en/rechtsprechung/verwaltungsgerichtsbarkeit

15. Bödefeld A., Knorr G. (2018) Tax litigation in Germany: overview. URL: https://uk.practicallaw.thomsonreuters. com/9-623-5696?transitionType=Default\&contextData=(sc.Default)\&firstPage=true\&bhcp $=1$.

16. Schachner G., Wittmann K., Wolski N., Hora L. (2020). Austria. The Tax Disputes and Litigation Review Edition 8. URL: https://thelawreviews.co.uk/edition/the-tax-disputes-and-litigation-review-edition-8/1215534/austria.

17. Jacquot N., Taxand A., Mispelon P. (2018). Tax litigation in France: overview. URL: https://uk.practicallaw. thomsonreuters.com/5-624-3429?transitionType=Default\&contextData=(sc.Default)\&firstPage=true\&bhcp=1\#co_ anchor_a933180.

18. Appeals Reviews and Tribunals Guidance : UK HMRC Internal Manual of 5 March 2016 (updated: 11 May 2020). URL: https://www.gov.uk/hmrc-internal-manuals/appeals-reviews-and-tribunals-guidance/artg12010.

19. 19. Whitehead S. (2015) The Tax Disputes and Litigation Review. Law Business Research: 3d Edition. Toronto, Ontario: $418 \mathrm{p}$.

\section{REFERENCES}

1. Zaproponovani zakonoproektom № 2314 fil'try spryiatymut' zabezpechenniu iednosti sudovoi praktyky, chlen Komisii z pytan' pravovoi reformy Roman Bojko [The filters laid out in draft law no. 2314 will contribute to the conformity of the case-law, - Roman Boyko, member of the Legal Reform Commission]. Sudovo-yuridichna gazeta. 2019. URL: https://ki.arbitr.gov.ua/sud5011/pres-centr/interview/855463/. (in Ukrainian).

2. Paseniuk, O. M. (2018). Kolizii mizh administratyvnoiu ta hospodars'koiu iurysdyktsiieiu: shliakhy ikh podolannia [Conflicts between administrative and economic jurisdiction: ways to overcome them]. Yurinkom Inter. URL: https://yurincom.com/legal_practice/analitychna_yurysprudentsiia/kolizii-mizh-administratyvnoiu-tahospodarskoiuiurysdyktsiieiu-shliakhy-ikh-podolannia/. (in Ukrainian).

3. Stefaniuk, V.S. (2003). Sudovyj administratyvnyj protses [Administrative court proceedings]: monograph. Kharkiv: Company «Konsum». (in Ukrainian).

4. The Code of Administrative Proceedings of Ukraine: a Statute of Ukraine of 6 July 2005 № 2747-IV. Last amended: 5 August 2021. URL: https://zakon.rada.gov.ua/laws/show/2747-15\#n9495. (in Ukrainian).

5. The Code of Administrative Proceedings of Ukraine: a Statute of Ukraine of 6 July 2005 № 2747-IV. URL: https://zakon.rada.gov.ua/laws/show/2747-15/ed20050706/conv\#Text. (in Ukrainian).

6. Jungment of the Supreme Court of Ukraine of 6 September 2016 in case no. 21-966a16. URL: https:// protocol.ua/ua/vcu_pidtverdiv_viklyuchne_pravo_advokativ_samostiyno_virishuvati_spirni_pitannya_shchodo_ samovryadnosti/. (in Ukrainian).

7. Jungment of the Supreme Court of Ukraine (Grand Chamber) of 7 November 2018 in case no. 553/4650/14a (K/9901/1396/18). URL: http://reyestr.court.gov.ua/Review/77801686. (in Ukrainian).

8. Jungment of the Supreme Court of Ukraine (Grand Chamber) of 13 November 2018 in case no. 910/2145/18. URL: http://reyestr.court.gov.ua/Review/78044739. (in Ukrainian).

9. Jungment of the Supreme Court of Ukraine of 6 May 2020 in case no. 761/9550/17. URL: http://reyestr.court. gov.ua/Review/89621251. (in Ukrainian).

10. Jungment of the Supreme Court of Ukraine (Grand Chamber) of 11 December 2018 in case no. 910/8122/17. URL: http://reyestr.court.gov.ua/Review/78977479. (in Ukrainian).

11. Jungment of the Supreme Court of Ukraine (Grand Chamber) of 21 November 2018 in case no. 804/8507/15. URL: http://reyestr.court.gov.ua/Review/78129846. (in Ukrainian).

12. Jungment of the Supreme Court of Ukraine (Grand Chamber) of 28 November 2018 in case no. 815/3490/16. URL: http://reyestr.court.gov.ua/Review/78299081. (in Ukrainian).

13. Jungment of the Supreme Court of Ukraine (Grand Chamber) of 21 November 2018 in case no. 805/1983/17a. URL: https://protocol.ua/ru/postanova_vp_vs_vid_21_11_2018_roku_u_spravi_805_1983_17_a/. (in Ukrainian).

14. Federal Administrative Court of the Federal Republic of Germany. Administrative Jurisdiction. URL: https:// www.bverwg.de/en/rechtsprechung/verwaltungsgerichtsbarkeit

15. Bödefeld, A., Knorr, G. (2018) Tax litigation in Germany: overview. URL: https://uk.practicallaw.thomsonreuters. com/9-623-5696?transitionType=Default\&contextData=(sc.Default)\&firstPage=true\&bhcp $=1$.

16. Schachner, G., Wittmann, K., Wolski, N., Hora , L. (2020). Austria. The Tax Disputes and Litigation Review Edition 8. URL: https://thelawreviews.co.uk/edition/the-tax-disputes-and-litigation-review-edition-8/1215534/austria.

17. Jacquot, N., Taxand, A., Mispelon, P. (2018). Tax litigation in France: overview. URL: https://uk.practicallaw. thomsonreuters.com/5-624-3429?transitionType=Default\&contextData=(sc.Default)\&firstPage=true\&bhcp=1\#co_ anchor_a933180.

18. Appeals Reviews and Tribunals Guidance : UK HMRC Internal Manual of 5 March 2016 (updated: 11 May 2020). URL: https://www.gov.uk/hmrc-internal-manuals/appeals-reviews-and-tribunals-guidance/artg12010.

19. Whitehead, S. (2015) The Tax Disputes and Litigation Review Law Business Research: 3d Edition. Toronto, Ontario. 